\title{
Women's Employment in Nutmeg Industry to Improve the Welfare of Family at Tuminting Sub- District Manado City
}

\author{
${ }^{1}$ Fonny Rewah* \\ Geography Education Department \\ Faculty of Social Science \\ Universitas Negeri Manado \\ Tondano, Indonesia \\ fonnyrewah@unima.ac.id
}

\author{
${ }^{2}$ Xaverius Erick Lobja \\ Geography Education Department: \\ Faculty of Social Science \\ Universitas Negeri Manado \\ Tondano, Indonesia \\ ericklobja@unima.ac.id
}

\author{
${ }^{3}$ Ellen Eva Poli \\ Geography Education Department \\ Faculty of Social Science \\ Universitas Negeri Manado \\ Tondano, Indonesia \\ ellenpoli@unima.ac.id
}

\begin{abstract}
The purpose of this study was to determine the socio-economic conditions of the female workforce community in the nutmeg industry improve family welfare in the Tuminting sub-district of Manado. The method used in this study was a qualitative research method with a phenomenological approach. Based on the results of the study, it shows: (1) The socio-economic situation of women workers who work in the nutmeg industry in general from disadvantaged family backgrounds, both unable in terms of educational background or terms of family needs. Before working, family income is not sufficient and the needs of daily life coupled with various problems in the family include a large number of dependents in the family income is not sufficient due to the husband's condition that is no longer possible to make a living, and the husband's basic work. In improving welfare related to terms of basic needs, after working as a workforce in the nutmeg industry, the food needs only for daily life and impact on children's education. Educational needs of children in terms of sending their children to school; (2) Factors encourage female workers who work in the nutmeg industry due to family conditions are lacking to supply income to prosper the family, are not required to have an educational background or have a diploma but only with experience and perseverance. The opportunity is supported by the guarantee of labor welfare after entering the end of work, to work additional to fulfill family needs. Also, it has a purpose and hopes to be able to continue children to school.
\end{abstract}

Keywords: Labor, Women, Welfare, Industry

\section{INTRODUCTION}

Tuminting sub-district is one of 10 sub-district located in Manado City. The total population in 2015 was 5,187 people and the Head of the Family (KK) was 1,846 , consisting of 2,552 men and 2,635 women with a population density of about 141 people / Km. more than $50 \%$ of the population of the Tuminting sub-district are included in the productive age group of work and less than 505 working-age productive groups.

Based on Law No. 13 of 2003[1] concerning manpower, which called labor is everyone who able to do work to produce goods and services both to meet their own needs and the community. Economic growth is very fast marked by the growth of new industries create many opportunities for the workforce, both men and women. Most jobs in companies do not require special skills to provide a great opportunity for women workers. Urgent economic demands, inadequate needs, un well-being and opportunities to work in the industry are put to good use by women, especially mothers.

Every human being is certainly hoping for welfare in the family or their needs are met, both the needs of the family and individual needs. Food needs in a family is an absolute should be met. For this reason, how is it every family, including every family member, should strive to work to meet the needs of the family, especially food needs or often said to be basic needs.

The most common thing can be seen is most of the people who work to fulfill their family's basic needs are the head of the household. However, the phenomenon that occurred in several families in the Tuminting is the income derived from the work of a household head who on average is only a handyman, bassist, petty trader, motorcycle taxi driver, and driver cannot supply the basic needs of the family, which classified as poor. This requires housewives in Tuminting District to participate in efforts to fulfill the needs of families by working as workers in the nutmeg processing industry.

The community of women, especially mothers in Tuminting who work as laborers in the nutmeg industry, has a very big role in improving the economy, especially families. Family income based on husband's income the average monthly is only around Rp. 2,200,000 who on average have only one building and a widow, whose daily income does not reach the North Sulawesi Provisional standard (UMP) Rp. 2,598,000, then the number of children more than 2 in school-age should be financed and schooled, meanwhile the price of necessities is increasingly expensive. As the requires women, especially these mothers to work as daily laborers, earning received around Rp. $900 / \mathrm{Kg}$ and usually 1 day is only able to process $80 \mathrm{Kg}$ which means the income is only Rp. 72,000 / day or Rp. 1,728,000 / month. As the daily workforce, the income received ranges from Rp. 75,000 to Rp. 100,000 / day or around Rp. $1,800,000$ to 
Rp. 2,400,000 / month. The number of workers in the industrial sector in Manado is 7,292 people, 5,362 men and 1,930 women [2]. The land of North Sulawesi is known for its abundance of nutmeg plant commodities found in North Sulawesi itself. This is caused by entrepreneurs to start exploiting by making the nutmeg processing industry. The average nutmeg industrial company in North Sulawesi has workers who generally live around this company. Their residence is close to the nutmeg processing industry (nutmeg warehouse) and their residence is also close to the owner of the industrial company in the case of nutmeg processing, Means there are opportunities for women in Tuminting to try to increase income for family needs by becoming a worker in the nutmeg processing industry.

One of the basic problems often occurs in the community is the problem of the basic needs of life or the economic needs of all the existing needs. It can be realized the economic and social activities of the population coupled with high needs increasingly require space to increase the activities of the population, it causes an increased need for someone. There are several things cause the family's needs are not enough. One of them is the lack of capital to try, both in the form of material capital and for educational background abilities. Living in the current era of globalization requires everyone to have at least the ability of educational capital and skills to be able to compete for work. To be a farmer or fisherman should have at least a basic ability to cultivate the land and catch fish.

In general, we know Indonesian housewives in ancient times could only do the basic tasks of a housewife, for example taking care of the household in cooking, washing clothes, serving her husband, caring for children. These jobs are considered as the nature of womanhood. Then in ancient times, there were also boundaries between male and female occupations. This limitation separates the work of men which should not be done by women, but also vice versa there are women's jobs that should not be done by men. For example, a man's duty in agriculture is hoeing and plowing a field, while a woman's job is cooking, and it will taboo if the task is swapped.

But recently have changed, housewives no longer only do household chores, but mothers can do work like a man. Housewives can change their husbands' jobs if needed. Housewives are required to be able to play a role in the family, community, and country. Housewives can also develop themselves for they can enjoy and take advantage of opportunities for a career besides the household without leaving work as a housewife.

Based on the background of the problems, the purpose of the study is to describe the socio-economic conditions of the community of women workers in the nutmeg industry in improving family welfare in the Tuminting sub-district, Manado City.

\section{RESEARCH METHODS}

The method used in this study is a qualitative research method with a phenomenological approach. According to Bogdan and Taylor [3] qualitative methodology as a research procedure that produces descriptive data in the form of written or oral words from people and observable behavior.

Qualitative research is research intends to understand the phenomenon of what can be observed. Qualitative is research to understand phenomena about an experienced by research subjects such as behavior, motivational perceptions, actions, etc. holistically and using descriptions in the form of words and language, in a special natural context by utilizing various natural methods. This study aims to determine, describe, and analyze the socio-economic situation of female labor households in the nutmeg industry as an effort to improve family welfare. Therefore, this study uses a phenomenological approach trying to explain or uncover the meaning of concepts or experience phenomena that are based on the phenomena of the experiences of several individuals. By using a qualitative research method with a phenomenological approach, which aims to provide a systematic, factual and accurate picture of the focus of the problem namely on the Social Economic Conditions of the Community of Women Workers in the Nutmeg Industry in Improving Family Welfare in Tuminting subdistrict of Manado.

\section{RESULT AND DISCUSSION}

The results of the analysis of the explanations and responses from informants related to the socioeconomic background of workers in the industry is an effort to improve family welfare due to general the average female workforce in the nutmeg industry comes from outside of Manado, namely from Sangihe in general. Neither can afford in terms of educational backgrounds ranging from elementary, junior high, high school, to fulfill family needs. It is known the average age of female workers in the nutmeg industry is classified as productive working age, namely 17-60 years. Before working, family income has not been enough for the needs of daily life with various problems in the family. Life takes care of the household because it has to be a mother who doubles as a father (single parent), the condition of a husband who is weak and no longer possible to make a living as well as the number of dependents in the family trying to make a living to fulfill the needs of family life including basic needs such as food and children's education.

After working as a labor in the nutmeg industry, the needs of the family in its food needs can be sufficient even though it does not reach 4 perfect healthy or limited to survive. Working as a labor in the nutmeg industry has an impact on children's education. Educational needs in terms of schooling even though only to high school level and can work as an entrepreneur most importantly exceed parental education. 
The mothers who are supposed to take care of the household and children but are encouraged to work as laborers in the nutmeg industry, due to families who are still lacking an effort to increase income for the welfare of the family. Besides, to be a workforce in the nutmeg industry is not required to have an educational background and have a diploma, but all needed is good work experience beforehand through training for 3 months and perseverance. One of the facilities also encourages is a different way of working, some workers are paid according to the piece of work who can profit at any time can go home even though their income is small, then some workers are paid daily with greater income but no time for permission to leave when you come to work. Besides, due to the distance of the place of work adjacent to the house, it can be reached by walking 5 minutes from the house. Then when they reach the age of 56 the workers in the nutmeg industry should end the period of work, but there is a guarantee of welfare even though entering the end of the work period. The guarantee is in the form of receiving severance pay. The amount of severance received varies according to the length of service of each workforce.

In this study, according to Crow and Allan [4], the Community can be divided into 2 components:

1. Based on Location or Place The area or place of a community seen as a place where a group of people has something in common geographically

2. Based on Interests A group of people who establish a community due to having the same interests, for example, religion, occupation, ethnicity, race, or based on sexual disorders.

Women workers who work in industries in the Tuminting sub-district are said to be a community due to geographically. there is a locality bond between these female workers who live in the Tuminting sub-district, especially in the 5 Neighborhood. Furthermore, they have the same linkages and interests, namely as workers in the nutmeg industry.

\section{Socio-economic justice of female workers in the nutmeg industry}

Based on the results of the study, the average female workforce in the nutmeg industry came from outside the city of Manado, namely from Sangihe in general from disadvantaged family backgrounds. Neither can afford in terms of educational background that on average most of them have education starting from elementary, junior high, high school level, as well as in terms of meeting the needs of family life. Then it is known that the average age of female workers who work in the nutmeg industry is classified as productive working age, which is 17-60 years. Before work, family income is not enough and fulfills the needs of daily life with various problems in the family. Life takes care of the household because it has to be a mother who doubles as a father (single parent), a weak husband's condition that is no longer possible to make a living, as well as the work of a husband who is makeshift so that he tries to earn a living to supplement his income to meet family life needs including necessities like food and children's education.

According to Joseph Schumpeter in Damsar [5], asserted that economic analysis is to study how people behave at a certain time and what is the influence of their behavior. While Economic Sociology has to study why they conduct such behavior in a broader institutional context where economic activity is carried out. Associated with the results of this study, that the behavior of women workers in the nutmeg industry who decided to engage in earning activities due to inadequate family income and meet the needs of daily life with a variety of problems in the family and the conditions left by the husband, the husband's weak condition which is no longer possible to earn a living, as well as the husband's improvised work. In the family, it can be decided who family members do work and other things such as housewives who work for a living based on consideration in a household.

The goal is an effort to increase income to fulfill family needs, including basic needs such as food and children's education. According to Damsar [5], Economic sociology can be defined in two ways. First, economic sociology is defined as a study that studies the relationship between people in which social interaction with the economy occurs. Society as an external objective reality will guide individuals in carrying out economic activities. Everyone needs good food, clothing, and shelter to survive. Therefore, every human being needs to work to meet these needs for the sake of welfare in the family. Measuring the level of welfare is measured in 3 aspects namely food needs, clothing, and shelter. After working as a labor in the nutmeg industry, the needs of the family in which food needs can be met even though they do not reach 4 perfectly healthy or can live life.

According to Abu Ahmadi [6], it is the function of education. The function of this education can be applied by sending the children according to age development. It is expected that by being given education through schools, children will have knowledge, skills, and behavior development. To this research, working as a workforce in the nutmeg industry aims and impacts on children's education. Educational needs in terms of sending children to school even though only up to high school level and can work as entrepreneurs, the most important thing can exceed parental education according to indicators of the level of family welfare According to Badan Pusat Statistik (BPS) [7], there are 8 indicators, one of which is the ease of entering children in education consists of 3 items namely school fees, school distance, and admission process. 


\section{Factors that encourage female workers who work in the nutmeg industry}

Based on interviews with several informants, the main tasks of mothers who should take care of the household and children, as stated in Effendy [8], a housewife is a mother who plays a role in taking care of the household such as cooking, washing, sweeping, et cetera; nurture and educate their children and as a group of social roles; meeting the affective and social needs of children; as well as being an active and harmonious member of the community that is manifested in various activities. But then they are motivated to work for a living as workers in the nutmeg industry, an effort to increase income for the welfare of the family. According to Sajogjo [9], housewives have 2 types of roles:

1. The full role of housewives is only in housework or life maintenance work needs of all family members, such as cooking, educating children and serving their husbands.

2. The role of housewives has a dual role, namely changes in work earning a living.

Women's occupation according to Munandar [10] the factor of working women is:

1. Increase family income

2. Does not depend entirely on the husband

3. Can fill up free time

The duty of housewives is not only within the family but also plays a role outside the home such as female labor in the nutmeg industry to improve family welfare. Besides, to be a workforce in the nutmeg industry is not required to have an educational background and have a diploma, but all that is needed is good work experience before or through training for 3 months and perseverance. One of the facilities encourages is a different way of working, some workers are paid according to the piece of work who earned at any time can go home even though their income is small, then some workers are paid daily with greater income but no time for permission to leave when you come to work. Besides, due to the distance of the workplace adjacent to the house, it can be reached by walking 5 minutes from home.

Then when they reach the age of 56 the workers in the nutmeg industry should end the period of work, but there is a guarantee of welfare despite entering the end of work. The guarantee is in the form of severance pay. The amount of severance received varies according to the length of service of each workforce. According to labor social security law, No. 3 of 1992 [11]: First, providing basic protection to meet the minimum living needs for the workforce and their families. Second, it is an appreciation for workers to educate workers' independence for workers who do not have to ask for the mercy of others if there is a risk in work relationships such as accidents, old age, illness, and others.

\section{CONCLUSION}

Based on the discussion of the results of the study, regarding female workers in the nutmeg industry, it can be concluded as follows:

1. The socioeconomic of women workers in the nutmeg industry generally from disadvantaged family backgrounds, both unable in terms of educational background and terms of the needs of family life. Before working, family income is not sufficient and fulfill the needs of daily life coupled with various problems in the family including a large number of dependents in the family, income is not sufficient due to the husband's condition is no longer possible to make a living and the husband's basic work. In improving welfare related to welfare in terms to fulfill basic needs, after working as a workforce in the nutmeg industry, food needs can be sufficient and even can only survive and impact on children's education. Children's educational needs in terms of sending their children to school.

2. Factors encourage female workers who work in the nutmeg industry to see the condition of families who are still lacking to increase income to prosper the family, are not required to have an educational background or have a diploma but only with experience and perseverance.

Opportunities are supported by guarantees of labor welfare after entering the end of work, can work additional to fulfill family needs. Besides, it has a purpose and hopes to be able to send children to school.

\section{Suggestion}

According to the results of research and conclusions have been described, it is necessary to give some suggestions:

1. For the community, especially mothers who have extra work for their work goodly. honest, diligent, to fulfill family needs by not leaving the main task as a housewife.

2. For those who have industries more specifically the nutmeg industry to workers, especially in terms of granting rights to workers, for the industrial business runs well and benefits both workers and owners.

\section{ACKNOWLEDGMENT}

Thank you for Dean Faculty of Social Sciences for supporting this research.

\section{REFERENCES}

[1] R. Indonesia, "Undang-Undang Republik Indonesia No.13 Tahun 2003 tentang Ketenagakerjaan," Undang. No.13 Tahun 2003, no. 1, pp. 1-34, 2003, [Online]. Available:

http://www.kemenperin.go.id/kompetensi/UU_13_200 3.pdf. 
[2] Badan Pusat Statistik, Manado DALAM ANGKA 20042005. Manado: Badan Pusat Statistik, 2009.

[3] D. M. A. Lexy J. Moleong, "Metodologi Penelitian Kualitatif (Edisi Revisi)," PT. Remaja Rosda Karya, 2019, doi: 10.1016/j.carbpol.2013.02.055.

[4] G. Crow, Graham and Allen, Community life: an introduction to local social relations. New York, USA.: Harvester Wheatsheaf, 1994.

[5] Damsar, Pengantar Sosiologi Pendidkan. Jakarta: Kencana, 2011.

[6] Suhendi, Hendi. ;Ramdani. Wahyu, Pengantar Studi Sosiologi Keluarga, 1st ed. Bandung: CV Pustaka Setia, 2001.

[7] Badan Pusat Statistik, Statistik Indonesia 2005/2006, 1st ed. Jakarta: Badan Pusat Statistik, 2005.
[8] O. U. Effendy, Ilmu, Teori dan Filsafat Komunikasi. 2003.

[9] P. Sajogjo, Sosiologi Pedesaan, Jilid I da. Yogyakarta: Gadjah Mada University Press, 1986.

[10] A. et. al. Mudzhar, Women in Indonesia: Access, Empowerment, and Opportunity. Yogyakarta: Sunan Kalijaga Press, 2001.

[11] P. R. Indonesia, "Undang-undang No. 3 Tahun 1992 tentang JAMINAN SOSIAL TENAGA KERJA," vol. 21, no. 1, pp. 1-9, 1992. 